\title{
Comparison of freshly cultured versus freshly thawed (cryopreserved) mesenchymal stem cells in preclinical in vivo models of inflammation: a protocol for a preclinical systematic review and meta-analysis
}

Chintan Dave ${ }^{1}$, Andrea McRae ${ }^{2}$, Emily Doxtator ${ }^{2}$, Shirley H. J. Mei ${ }^{2}$, Katrina Sullivan², Dianna Wolfe ${ }^{3}$, Josee Champagne ${ }^{2}$ and Lauralyn McIntyre ${ }^{1,4^{*}}$ (D)

\begin{abstract}
Background: Mesenchymal stem cells (MSCs) are multipotent cells that demonstrate therapeutic potential for the treatment of acute and chronic inflammatory-mediated conditions. Especially for acute conditions, it is critical to have a readily available freshly thawed (cryopreserved) MSC product for rapid administration. Although controversial, some studies suggest that MSCs may lose their functionality with cryopreservation which in turn could render them non-efficacious.

Objective: In controlled preclinical in vivo models of inflammation, to determine if there are differences in surrogate measures of preclinical efficacy between freshly cultured and freshly thawed MSCS

Methods/design: A systematic search for pre-clinical in vivo inflammatory model studies will compare freshly cultured to freshly thawed MSCs from any source. The primary outcomes will include measures of in vivo preclinical efficacy; secondary outcomes will include measures of in vitro MSC potency. Electronic searches for MEDLINE and EMBASE will be constructed and reviewed by the Peer Review of Electronic Search Strategies (PRESS) process. If applicable, study outcomes will be meta-analyzed using a random effects model. Risk of bias will be assessed by the SYRCLE "Risk of Bias" assessment tool for preclinical in vivo studies.

(Continued on next page)
\end{abstract}

\footnotetext{
* Correspondence: Imcintyre@toh.ca

'Department of Medicine, The Ottawa Hospital, Ottawa, ON, Canada

${ }^{4}$ Division of Critical Care, Department of Medicine, The Ottawa Hospital,

Ottawa, ON, Canada

Full list of author information is available at the end of the article
}

(c) The Author(s). 2020 Open Access This article is licensed under a Creative Commons Attribution 4.0 International License, which permits use, sharing, adaptation, distribution and reproduction in any medium or format, as long as you give appropriate credit to the original author(s) and the source, provide a link to the Creative Commons licence, and indicate if changes were made. The images or other third party material in this article are included in the article's Creative Commons licence, unless indicated otherwise in a credit line to the material. If material is not included in the article's Creative Commons licence and your intended use is not permitted by statutory regulation or exceeds the permitted use, you will need to obtain permission directly from the copyright holder. To view a copy of this licence, visit http://creativecommons.org/licenses/by/4.0/. The Creative Commons Public Domain Dedication waiver (http://creativecommons.org/publicdomain/zero/1.0/) applies to the data made available in this article, unless otherwise stated in a credit line to the data. 
(Continued from previous page)

Discussion: The results of this systematic review will provide translational scientists, clinical trialists, health regulators, and the clinical and public community with the current pre-clinical evidence base related to the efficacy and potency of freshly cultured versus freshly thawed MSCs, help identify evidence gaps, and guide future related research.

Systematic review registration: Protocol is submitted to PROSPERO for registration (pending confirmation) and will be submitted to Collaborative Approach to Meta-Analysis and Review of Animal Data from Experimental Studies (CAMARADES) for public posting.

Keywords: Preclinical systematic review, Cryopreserved, Thawed, Fresh, Cultured, Mesenchymal stromal cells (MSCs), Animal model

\section{Background}

Since the first transplantation of stem cells in 1957, research has heavily focused on hematopoietic stem cells (HSCs), which have now become standard-of-care for many indications [1]. The success of these transplantations established a new paradigm for stem cell therapy in the past 30 years. In recent years, studies have found that mesenchymal stem cells (MSCs) have functions that are unique to traditional stem cell therapies related to immunomodulation, and without the need for engraftment into tissues [2]. Since the early 2000s, reports of immunomodulatory properties of MSCs from the bone marrow were emerging [3-5], and these were reproducible in various species and models, including human case reports, that found in vitro-cultured MSCs had immunosuppressive function [6-8]. These results were also reproduced in MSCs from sources other than the bone marrow [9, 10]. Furthermore, numerous animal model and translational studies have reported capacity of MSCs to home to sites of injury/inflammation and carry out their immunomodulatory function, which adds to their attractiveness for use in the clinical setting [11]. As of June 2020, there were 885 MSC-related clinical trials registered on the NIH Clinical Trial Database. An accumulation of small clinical trials are now published that have tested MSCs in a variety of clinical trials for heterogeneous inflammatory-mediated conditions, examples include multiple sclerosis [12], graft-versus-host disease [13-15], osteoarthritis [16-20], inflammatory bowel disease (IBD) [21, 22], various pulmonary inflammatory diseases [23-25], and septic shock [26]. The limitation with many of these studies and in future real-world therapeutic applications of MSCs is the logistical and financial challenges that come from isolating, culturing, and cryopreserving MSCs. The majority of preclinical MSC research have examined the use of freshly cultured MSCs. However, this approach may not be feasible for acute indications, such as septic shock, where an off-the-shelf MSC treatment is desired. There have been conflicting studies regarding the effect of cryopreservation on MSCs and their functionality. Some studies show that freshly cultured MSCs are more potent in an in vitro setting when compared to their cryopreserved counterpart [27, 28 ], whereas other studies demonstrate that cryopreservation does not negatively impact the potency or efficacy of MSCs [29-32]. Given this uncertainty, a review of the preclinical literature is necessary.

To begin to address this evidence gap, our team will conduct a systematic synthesis of all preclinical in vivo studies that examine surrogate measures of in vivo efficacy of freshly cultured and freshly thawed MSCs in animal models of inflammation. The results of this systematic review will provide translational scientists, clinical trialists, health regulators, and the clinical and public community with the current pre-clinical evidence base related to the efficacy and potency of freshly cultured versus freshly thawed MSCs, and help identify evidence gaps to guide future related research.

\section{Study question}

In controlled preclinical in vivo models of inflammation, are there differences in surrogate measures of preclinical efficacy between freshly cultured and freshly thawed MSCs?

\section{Methods/design \\ Protocol and registration}

The systematic review protocol was developed through discussions with our team of clinical (LM, CD) and preclinical research scientists (LM, SM, AM), an information specialist (AM), and experts in knowledge synthesis and translation (LM, AM, JC, DW). This systematic review will be conducted in consultation with the Cochrane Handbook and reported in accordance with the Preferred Reporting Items for Systematic Review and Meta-Analysis (PRISMA) guidelines [33, 34]. A copy of the PRISMA checklist will be provided as part of the supplementary documentation with the final report. The protocol will be registered within the International Prospective Register of Systematic Reviews (PROSPERO) and with the Collaborative Approach to Meta-Analysis 
and Review of Animal Data from Experimental Studies (CAMARADES) group.

\section{Study eligibility \\ Study design}

Preclinical studies of in vivo models of inflammation that compare freshly cultured to freshly thawed MSC products (randomized, quasi-randomized, and nonrandomized) will be included. Studies that only describe in vitro experiments comparing freshly cultured to freshly thawed MSC products will be excluded.

\section{Population (preclinical model)}

The population will include animal model of acute or chronic inflammation. These animal models (Table 1) may be diverse given that there are many human clinical diseases or conditions that are associated with inflammation [35-37]. Inflammation is the response, through the innate and adaptive immune system and inflammatory mediators, of the host to harmful stimuli, such as pathogens, cell damage, or irradiation. A series of coordinated and shared mechanisms and pathways of inflammation contribute to diverse clinical presentations [38]. Consequently, studies will be considered as models of inflammation if they are designed to mimic a clinical condition or syndrome that is associated with an inflammatory process. Studies that include immunocompromised animals (SCID) or treatments to immunosuppress the animals or that focus on the effects of MSCs on implantation and tissue regeneration (e.g., bone regeneration) will be excluded.

\section{Intervention and comparison}

Both the intervention and comparison groups will include the administration of MSCs that are derived from any MSC origin (bone marrow, adipose tissue, umbilical cord, or other) and source (xenogeneic, syngeneic, autologous, or allogeneic). MSCs must be administered during or after the induction of the experimental pre-

Table 1 Common examples of preclinical in vivo models of inflammation that have been used to assess in vivo markers of pre-clinical efficacy and/or in vitro MSC potency

\begin{tabular}{l} 
Models of inflammation \\
\hline Sepsis \\
Acute lung injury \\
Inflammatory airway disease \\
Ischemia-reperfusion injury \\
Acute and chronic arthritis \\
Chronic kidney disease \\
Hindlimb ischemia \\
Closure of acute and chronic skin wounds
\end{tabular}

clinical model (i.e., studies evaluating the preventive effects of MSCs will be excluded). All MSC delivery routes will be included. All differentiated MSCs (e.g., differentiated into a myocyte), mesenchymal progenitor cells (MPCs), mononuclear cell (MNC) fraction, and any stem cells that are not described as MSCs will be excluded. Non-MSC comparison groups (e.g., phosphate-buffered saline, fibroblasts) will also be described to examine the magnitude of the effect for the proposed outcomes (surrogate markers of preclinical in vivo efficacy and in vitro potency).

The intervention group will include freshly thawed MSCs. To be considered freshly thawed, MSCs need to be cryopreserved for any duration of time and be placed in culture for less than $24 \mathrm{~h}$ post-thaw prior to use in the given experiment. The comparison group will be freshly cultured MSCs. MSCs will be considered freshly cultured when the cells are either in continuous culture or cryopreserved but then thawed and placed in culture for at least $24 \mathrm{~h}$ prior to use in experiments. We used this 24 -h culture time as a cutoff as previous experiments have demonstrated that cryopreserved MSCs may require $24 \mathrm{~h}$ of culture to recover their functionality [39].

MSCs that are pre-treated, pre-conditioned, genetically altered, or co-administered with other experimental interventions will be included if the same alteration is applied to both the freshly cultured and freshly thawed MSCs.

\section{Outcomes}

The primary outcome measures are surrogate measures of in vivo preclinical efficacy that are relevant to specific acute and chronic inflammatory animal models and are defined by two outcome domains: (1) organ dysfunction and composition of tissues (e.g., histopathological damage) and (2) protein expression and secretion (e.g., cytokine levels, immunohistochemistry analysis).

Our secondary outcomes include the measures of in vitro MSC potency (that may be described as additional experiments in the included in vivo studies). Ideally, potency should represent the MSCs' mechanism of action; however, MSCs have complex and multiple mechanisms of action, all of which are not yet fully characterized or reported [40]. The International Society for Cellular Therapy has recently published a perspective paper on this topic [40] and suggest assessing MSC potency based on an assay matrix, namely, a collection of assays. These include a combination of in vitro analytical and/or biological assays. Examples of analytical in vitro assays include an assessment of the cellular secretome by ELISA (enzyme-linked immunosorbent assay) or of functional cell-based assays (in vitro assay culturing MSCs with responder immune cells). Hence, the two 
main secondary in vitro potency outcome domains include (1) co-culture assays and (2) protein expression and secretion.

\section{Information sources}

Search strategies will be developed and tested through an iterative process by an experienced medical information specialist in consultation with the research team. Six target articles provided by an expert in the field of preclinical research $(\mathrm{SM})$ that were known prior to the development of the search strategy have been included in the search criteria to help capture all potential studies. Using the Ovid platform, Ovid MEDLINE ${ }^{\oplus}$, OvidMEDLINE $^{\oplus}$ In-Process \& Other Non-Indexed Citations, and Embase Classic plus Embase will be searched. Additional searches will be performed on BIOSIS and Web of Science using Web of Knowledge. The strategy will be reviewed by another senior information specialist using the Peer Review of Electronic Search Strategies (PRESS) template. Search strategies will use a combination of controlled vocabulary (for example, mesenchymal stem cells, cryopreserved, acute or chronic inflammation) and keywords (for example, MSCs, cryopreservation, freshlythawed, fresh). Vocabulary and syntax will be adjusted across the databases. No additional filters will be employed to ensure the largest number of relevant studies are captured. There will be no language or date restrictions on any of the searches. The proposed preliminary search strategy with all studies included until June 20, 2019, appears in Supplemental Table 1. The bibliographies of included studies and pertinent reviews will also be hand searched for further relevant studies.

\section{Study selection}

The titles and abstracts of the search results will be screened independently by two investigators (CD, ED). The full-text of all potentially eligible studies will be retrieved and reviewed for eligibility, independently, by two members of the team using the a priori inclusion criteria described above. Disagreements between reviewers will be resolved by consensus or by a third member of the systematic review team (LM, SM).

\section{Data collection and process and data items}

Data will be extracted independently by two members of the research team into standardized, pilot-tested Excel sheet forms. For all relevant outcomes, all variables of the in vivo and in vitro experiments will be collected, including control groups employed for each experiment/ assay. Moreover, all details surrounding the cryopreservation process and the setup of the above experiments will be collected to understand any heterogeneity in cryopreservation and culture processes. Mean and standard deviation will be collected from the available data; if these are not available, the data provided from the study will be collected. MSCs will be characterized using the International Society of Cellular Therapy (ISCT) consensus statement (e.g., adherence to plastic, tri-lineage differentiation), but this will not be used as strict inclusion criteria. Specific data elements are listed in Table 2. The research team will contact authors of included studies

Table 2 Data collection elements

\begin{tabular}{|c|c|}
\hline Category & Specific items \\
\hline Study characteristics & Study title, author, date of publication, journal published, country of publication, randomization process \\
\hline Study population (animal model) & Animal type, age, gender, strain, and weight, presence of co-morbid illnesses \\
\hline $\begin{array}{l}\text { Model of inflammation and method } \\
\text { of induction }\end{array}$ & $\begin{array}{l}\text { Acute or chronic, direct or indirect infection, chemical-induced injury, ischemia-reperfusion, surgically } \\
\text { induced model, details of model induction process }\end{array}$ \\
\hline Intervention and comparison & $\begin{array}{l}\text { International Society for Cellular Therapy criteria, MSC tissue source, MSC characteristics (including method } \\
\text { of sorting), time and route of MSC administration, description of preparation and suspension of MSCs and } \\
\text { controls (including medium used for cells, duration of culture, passage number, concentration/amount of } \\
\text { MSCs used), vehicle used for delivery, storage conditions, cryopreservation methods (duration of } \\
\text { cryopreservation, method used to cryopreserved MSCs, and concentration of MSCs during cryopreservation, } \\
\text { and medium used to cryopreserve and whether any additives were used), post-thaw washing procedure } \\
\text { and time to use in experiment, time from disease induction to MSC administration, MSC viability, surface } \\
\text { marker expression }\end{array}$ \\
\hline
\end{tabular}

Co-interventions Antibiotics, cytokines, cultured medium, membrane/scaffold system employed

Potency

MSC secretome and release assay, MSC effect on various cells, and PBMC proliferation co-culture assay

Surrogate markers of efficacy

Preclinical outcomes that are relevant as per the model of inflammation employed and fall within the two domains of organ dysfunction and protein expression and secretion: examples include arterial oxygenation, lung compliance, neovascularization, epithelialization, wound contraction rate, arthritic index, histological lung injury, etc. 
for clarifications and to obtain additional information relevant to this review as appropriate.

\section{Assessment of risk of bias}

Risk of bias will be assessed independently by two reviewers (CD and $A M)$, and disagreements will be resolved via consensus or by a third reviewer when necessary. All studies will be assessed as having high, low, or unclear risk of bias for the 10 domains of bias adapted from the SYRCLE "Risk of Bias" assessment tool for preclinical in vivo studies [41]. This tool has been adapted from the Cochrane Collaboration Risk of Bias tool employed in clinical studies, with the aim to incorporate key elements that are relevant for in vivo animal studies. A table of the 10 risk of bias domains is provided in the Appendix (Table 3). To date, no validated tool is available for the evaluation of risk of bias for in vitro studies, which is mainly driven by poor reporting of in vitro studies, limiting the assessment of internal validity, and the complexity/ non-reproducible nature of many in-vitro experiments [42]. However, an adaptation based on the Cochrane Risk of Bias Tool and previous risk of bias assessments for in vitro systematic reviews to describe risk of bias elements that are relevant to in vitro studies is under development by our group [43-45].

\section{Data analysis}

Given the broad range of models of inflammation that are likely to be included, the ability to conduct quantitative analyses may be limited. Thus, much of the synthesis may be qualitative but supported by quantitative data extracted from the included studies. These results will be narratively summarized and presented in tabular format. Meta-analyses will be conducted, if sufficient data are available and if appropriate: two or more studies with similar disease models for an in vivo pre-clinical efficacy outcome, with the same outcome definition, or two or more studies with a similar in vitro potency assay employed. For continuous endpoints, data will be pooled using the ratio of the weighted means method with inverse variance random effects modeling. The ratio of means effect estimate is preferred because (a) it is unitless and allows pooling of data with different units of measurement within the same outcome, (b) it does not require knowledge of pooled standard deviation, and (c) may be more interpretable to clinicians as compared to the standardized mean difference [46]. Data reported in non-standard format (e.g., mean \pm standard error, median, and range) will be converted to mean \pm standard deviation. Outcomes will be described at all experimental timepoints reported in the included studies to understand any short- and long- term effects. If possible, the effect of in vitro inhibition on peripheral blood mononuclear cells (PBMCs) in co-culture with MSCs will be pooled to provide a direct, quantitative comparison between the freshly cultured and freshly thawed MSC in vitro potency.

\section{Subgroup analyses}

If possible within the limitations of the data, subgroup meta-analyses will be considered to evaluate sources of high heterogeneity $\left(I^{2}\right)$ in our primary meta-analyses and will be hypothesis generating. Potential subgroups of interest include MSC source, route of MSC administration, and MSC preparation and cryopreservation method.

\section{Knowledge translation}

The results of this systematic review will be of interest to a broad audience which includes basic and clinical MSC research scientists, health regulators and funders, and the clinical and public community. We plan to present our findings at future national and international critical care and regenerative medicine meetings. This review will be reported in accordance with the Preferred Reporting Items for Systematic Reviews and Meta-Analyses (PRISMA) guidelines developed for proper reporting of clinical systematic reviews (see Additional File 1).

\section{Discussion}

Our systematic review will comprehensively summarize the pre-clinical research on in vivo surrogate markers of preclinical efficacy and in vitro potency of freshly cultured versus freshly thawed MSCs for acute and chronic inflammatory conditions. Our review will systematically summarize the current evidence base, identify research gaps, and lay the groundwork for future related pre-clinical and clinical research studies.

Our protocol has strengths and limitations. The strengths are that we have designed a systematic, comprehensive, and transparent search to summarize the totality of the evidence. We have also established standardized definitions and methods for the approach to the analysis and interpretation of the included studies. A limitation of our review is that there may be limited opportunity to quantitatively summarize the study outcomes because of the broad pre-clinical model inclusion criteria. However, the broad inclusion criteria provide comprehensiveness to the study and we aim to qualitatively summarize these data for the readership. 


\section{Appendix}

Table $\mathbf{3}$ Sample of SYRCLE risk of bias tool employed for preclinical studies

\begin{tabular}{|c|c|c|c|c|}
\hline Item & Type of bias & Domain & Description of domain & Review authors judgment \\
\hline 1 & $\begin{array}{l}\text { Selection } \\
\text { bias }\end{array}$ & $\begin{array}{l}\text { Sequence } \\
\text { generation }\end{array}$ & $\begin{array}{l}\text { Describe the methods used, if any, to generate the } \\
\text { allocation sequence in sufficient detail to allow an } \\
\text { assessment whether it should produce comparable } \\
\text { groups. }\end{array}$ & $\begin{array}{l}\text { Was the allocation sequence adequately generated } \\
\text { and applied? }(*)\end{array}$ \\
\hline 2 & $\begin{array}{l}\text { Selection } \\
\text { bias }\end{array}$ & $\begin{array}{l}\text { Baseline } \\
\text { characteristics }\end{array}$ & $\begin{array}{l}\text { Describe all the possible prognostic factors or animal } \\
\text { characteristics, if any, that are compared in order to judge } \\
\text { whether or not intervention and control groups were } \\
\text { similar at the start of the experiment. }\end{array}$ & $\begin{array}{l}\text { Were the groups similar at baseline or were they } \\
\text { adjusted for confounders in the analysis? }\end{array}$ \\
\hline 3 & $\begin{array}{l}\text { Selection } \\
\text { bias }\end{array}$ & $\begin{array}{l}\text { Allocation } \\
\text { concealment }\end{array}$ & $\begin{array}{l}\text { Describe the method used to conceal the allocation } \\
\text { sequence in sufficient detail to determine whether } \\
\text { intervention allocations could have been foreseen before } \\
\text { or during enrolment. }\end{array}$ & Was the allocation adequately concealed? $\left(^{*}\right)$ \\
\hline 4 & $\begin{array}{l}\text { Performance } \\
\text { bias }\end{array}$ & $\begin{array}{l}\text { Random } \\
\text { housing }\end{array}$ & $\begin{array}{l}\text { Describe all measures used, if any, to house the animals } \\
\text { randomly within the animal room. }\end{array}$ & $\begin{array}{l}\text { Were the animals randomly housed during the } \\
\text { experiment? }\end{array}$ \\
\hline 5 & $\begin{array}{l}\text { Performance } \\
\text { bias }\end{array}$ & Blinding & $\begin{array}{l}\text { Describe all measures used, if any, to blind trial caregivers } \\
\text { and researchers from knowing which intervention each } \\
\text { animal received. Provide any information relating to } \\
\text { whether the intended blinding was effective. }\end{array}$ & $\begin{array}{l}\text { Were the caregivers and/or investigators blinded } \\
\text { from knowledge which intervention each animal } \\
\text { received during the experiment? }\end{array}$ \\
\hline 6 & $\begin{array}{l}\text { Detection } \\
\text { bias }\end{array}$ & $\begin{array}{l}\text { Random } \\
\text { outcome } \\
\text { assessment }\end{array}$ & $\begin{array}{l}\text { Describe whether or not animals were selected at random } \\
\text { for outcome assessment and which methods to select the } \\
\text { animals, if any, were used. }\end{array}$ & $\begin{array}{l}\text { Were animals selected at random for outcome } \\
\text { assessment? }\end{array}$ \\
\hline 7 & $\begin{array}{l}\text { Detection } \\
\text { bias }\end{array}$ & Blinding & $\begin{array}{l}\text { Describe all measures used, if any, to blind outcome } \\
\text { assessors from knowing which intervention each animal } \\
\text { received. Provide any information relating to whether the } \\
\text { intended blinding was effective. }\end{array}$ & Was the outcome assessor blinded? \\
\hline 8 & Attrition bias & $\begin{array}{l}\text { Incomplete } \\
\text { outcome } \\
\text { data }\end{array}$ & $\begin{array}{l}\text { Describe the completeness of outcome data for each } \\
\text { main outcome, including attrition and exclusions from the } \\
\text { analysis. State whether attrition and exclusions were } \\
\text { reported, the numbers in each intervention group } \\
\text { (compared with total randomized animals), reasons for } \\
\text { attrition or exclusions, and any re-inclusions in analyses for } \\
\text { the review. }\end{array}$ & $\begin{array}{l}\text { Were incomplete outcome data adequately } \\
\text { addressed? }\left(^{*}\right)\end{array}$ \\
\hline 9 & $\begin{array}{l}\text { Reporting } \\
\text { bias }\end{array}$ & $\begin{array}{l}\text { Selective } \\
\text { outcome } \\
\text { reporting }\end{array}$ & $\begin{array}{l}\text { State how selective outcome reporting was examined and } \\
\text { what was found. }\end{array}$ & $\begin{array}{l}\text { Are reports of the study free of selective outcome } \\
\text { reporting? }\left(^{*}\right)\end{array}$ \\
\hline 10 & Other & $\begin{array}{l}\text { Other } \\
\text { sources of } \\
\text { bias }\end{array}$ & $\begin{array}{l}\text { State any important concerns about bias not covered by } \\
\text { other domains in the tool. }\end{array}$ & $\begin{array}{l}\text { Was the study apparently free of other problems } \\
\text { that could result in high risk of bias? }\left(^{*}\right)\end{array}$ \\
\hline
\end{tabular}

*Items in agreement with the items in the Cochrane Risk of Bias tool

\section{Supplementary information}

Supplementary information accompanies this paper at https://doi.org/10. 1186/s13643-020-01437-z.

Additional file 1. It provides a completed PRISMA checklist for this systematic review.

Additional file 2: Table S1. Draft Search strategy.

\section{Acknowledgements}

Not applicable.

\section{Authors' contributions}

$L M, J C, S M, K S, A M$, and CD conceived the study design. CD, AM, and LM were responsible for initial drafting and manuscript revisions. CD, ED, AM, and $L M$ are responsible for the data collection. $K S, J C, S M$, and LM will provide critical revisions and statistical support. SM provided expertise in the design of preclinical systematic reviews. SM, AM, DW, and LM provided translational biology expertise, and provided oversight for planned eligibility criteria and outcome measures. All authors read and approved the final manuscript.

\section{Funding}

Not applicable.

\section{Availability of data and materials}

Not applicable.

Ethics approval and consent to participate

Not applicable.

\section{Consent for publication}

Not applicable.

\section{Competing interests}

The authors declare that they have no competing interests.

\section{Author details}

${ }^{1}$ Department of Medicine, The Ottawa Hospital, Ottawa, ON, Canada. ${ }^{2}$ Sinclair Centre for Regenerative Medicine, Ottawa Hospital Research Institute, 
Ottawa, ON, Canada. ${ }^{3}$ Knowledge Synthesis Group, Ottawa Hospital Research Institute, Ottawa, ON, Canada. ${ }^{4}$ Division of Critical Care, Department of Medicine, The Ottawa Hospital, Ottawa, ON, Canada.

\section{Received: 31 October 2019 Accepted: 29 July 2020}

Published online: 19 August 2020

\section{References}

1. Thomas ED, Lochte HL Jr, Lu WC, Ferrebee JW. Intravenous infusion of bone marrow in patients receiving radiation and chemotherapy. New England Journal of Medicine. 1957:257:491-6.

2. Von Bahr L, Batsis I, Moll G, Hagg M, Szakos A, Sundberg B, Uzunel M, Ringden O, Le Blanc K. Analysis of tissues following mesenchymal stromal cell therapy in humans indicates limited long-term engraftment and no ectopic tissue formation. Stem Cells. 2012;30(7):1575-8.

3. Bartholomew A, Sturgeon C, Siatskas M, Ferrer K, Mclntosh K, Patil S, Hardy W, Devine S, Ucker D, Deans R, Moseley A, Hoffman R. Mesenchymal stem cells suppress lymphocyte proliferation in vitro and prolong skin graft survival in vivo. Exp Hematol. 2002;30(1):42-8.

4. Di Nicola M, Carlo-Stella C, Magni M, Milanesi M, Longoni PD, Matteucci P, Grisanti S, Gianni AM. Human bone marrow stromal cells suppress Tlymphocyte proliferation induced by cellular or nonspecific mitogenic stimuli. Blood. 2002;99(10):3838-43.

5. Le Blanc K, Tammik L, Sundberg B, Haynesworth SE, Ringden O. Mesenchymal stem cells inhibit and stimulate mixed lymphocyte cultures and mitogenic responses independently of the major histocompatibility complex. Scand J Immunol. 2003;57(1):11-20.

6. Le Blanc K, Rasmusson I, Sundberg B, Gotherstrom C, Hassan M, Uzunel M, Ringden $\mathrm{O}$. Treatment of severe acute graft-versus-host disease with third party haploidentical mesenchymal stem cells. Lancet. 2004;363(9419):143941.

7. Nauta AJ, Fibbe WE. Immunomodulatory properties of mesenchymal stromal cells. Blood. 2007;110(10):3499-506.

8. Uccelli A, Moretta L, Pistoia V. Mesenchymal stem cells in health and disease. Nat Rev Immunol. 2008:8(9):726-36

9. Gotherstrom C, Ringden O, Tammik C, Zetterberg E, Westgren M, Le Blanc K. Immunologic properties of human fetal mesenchymal stem cells. Am J Obstet Gynecol. 2004;190(1):239-45.

10. Chang CJ, Yen ML, Chen YC, Chien CC, Huang HI, Bai CH, Yen BL. Placentaderived multipotent cells exhibit immunosuppressive properties that are enhanced in the presence of interferon-gamma. Stem Cells. 2006;24(11): 2466-77.

11. Griffin MD, Elliman SJ, Cahill E, English K, Ceredig R, Ritter T. Concise review: adult mesenchymal stromal cell therapy for inflammatory diseases: how well are we joining the dots? Stem Cells. 2013;31(10):2033-41.

12. Connick P, Kolappan M, Patani R, Scott MA, Crawley C, He XL, Richardson K Barber K, Webber DJ, Wheeler-Kingshott CA, Tozer DJ, Samson RS, Thomas DL, Du MQ, Luan SL, Michell AW, Altmann DR, Thompson AJ, Miller DH, Compston A, Chandran S. The mesenchymal stem cells in multiple sclerosis (MSCIMS) trial protocol and baseline cohort characteristics: an open-label pre-test: post-test study with blinded outcome assessments. Trials. 2011;12: 62.

13. Baron F, Lechanteur C, Willems E, Bruck F, Baudoux E, Seidel L, Vanbellinghen JF, Hafraoui K, Lejeune M, Gothot A, Fillet G, Beguin Y. Cotransplantation of mesenchymal stem cells might prevent death from graft-versus-host disease (GVHD) without abrogating graft-versus-tumor effects after HLA-mismatched allogeneic transplantation following nonmyeloablative conditioning. Biol Blood Marrow Transplant. 2010;16(6): 838-47.

14. Introna M, Lucchini G, Dander E, Galimberti S, Rovelli A, Balduzzi A, Longoni D, Pavan F, Masciocchi F, Algarotti A, Mico C, Grassi A, Deola S, Cavattoni I, Gaipa G, Belotti D, Perseghin P, Parma M, Pogliani E, Golay J, Pedrini O, Capelli C, Cortelazzo S, D'Amico G, Biondi A, Rambaldi A, Biagi E. Treatment of graft versus host disease with mesenchymal stromal cells: a phase I study on 40 adult and pediatric patients. Biol Blood Marrow Transplant. 2014;20(3): 375-81.

15. Perez-Simon JA, Lopez-Villar O, Andreu EJ, Rifon J, Muntion S, Diez CM, Sanchez-Guijo FM, Martinez C, Valcarcel D, Canizo CD. Mesenchymal stem cells expanded in vitro with human serum for the treatment of acute and chronic graft-versus-host disease: results of a phase I/II clinical trial. Haematologica. 2011;96(7):1072-6.
16. Emadedin M, Ghorbani LM, Fazeli R, Mohseni F, Moghadasali R, Mardpour S, Hosseini SE, Niknejadi M, Moeininia F, Aghahossein FA, Baghban ER, Vosough DA, Labibzadeh N, Mirazimi BA, Baharvand H, Aghdami N. Longterm follow-up of intra-articular injection of autologous mesenchymal stem cells in patients with knee, ankle, or hip osteoarthritis. Arch Iran Med. 2015; 18(6):336-44.

17. Jo CH, Lee YG, Shin WH, Kim H, Chai JW, Jeong EC, Kim JE, Shim H, Shin JS, Shin IS, Ra JC, Oh S, Yoon KS. Intra-articular injection of mesenchymal stem cells for the treatment of osteoarthritis of the knee: a proof-of-concept clinical trial. Stem Cells. 2014;32(5):1254-66.

18. Orozco L, Munar A, Soler R, Alberca M, Soler F, Huguet M, Sentis J, Sanchez A, Garcia-Sancho J. Treatment of knee osteoarthritis with autologous mesenchymal stem cells: 2-year follow-up results. Transplantation. 2014; 97(11):e66-8.

19. Vega A, Martin-Ferrero MA, Del Canto F, Alberca M, Garcia V, Munar A, Orozco L, Soler R, Fuertes JJ, Huguet M, Sanchez A, Garcia-Sancho J. Treatment of knee osteoarthritis with allogeneic bone marrow mesenchymal stem cells: a randomized controlled trial. Transplantation. 2015;99(8):1681-90.

20. Vives J, Oliver-Vila I, Pla A. Quality compliance in the shift from cell transplantation to cell therapy in non-pharma environments. Cytotherapy. 2015;17(8):1009-14.

21. Forbes GM, Sturm MJ, Leong RW, Sparrow MP, Segarajasingam D, Cummins AG, Phillips M, Herrmann RP. A phase 2 study of allogeneic mesenchymal stromal cells for luminal Crohn's disease refractory to biologic therapy. Clin Gastroenterol Hepatol. 2014;12(1):64-71.

22. Molendijk I, Bonsing BA, Roelofs H, Peeters KC, Wasser MN, Dijkstra G, van der Woude CJ, Duijvestein M, Veenendaal RA, Zwaginga JJ, Verspaget HW, Fibbe WE, van der Meulen-de Jong AE, Hommes DW. Allogeneic bone marrow-derived mesenchymal stromal cells promote healing of refractory perianal fistulas in patients with Crohn's disease. Gastroenterology. 2015; 149(4):918-27 e916.

23. Chang YS, Ahn SY, Yoo HS, Sung SI, Choi SJ, Oh WI, Park WS. Mesenchymal stem cells for bronchopulmonary dysplasia: phase 1 dose-escalation clinical trial. J Pediatr. 2014;164(5):966-72 e966.

24. Weiss DJ, Casaburi R, Flannery R, LeRoux-Williams M, Tashkin DP. A placebocontrolled, randomized trial of mesenchymal stem cells in COPD. Chest. 2013;143(6):1590-8.

25. Wilson JG, Liu KD, Zhuo H, Caballero L, McMillan M, Fang X, Cosgrove K, Vojnik R, Calfee CS, Lee JW, Rogers AJ, Levitt J, Wiener-Kronish J, Bajwa EK, Leavitt A, McKenna D, Thompson BT, Matthay MA. Mesenchymal stem (stromal) cells for treatment of ARDS: a phase 1 clinical trial. Lancet Respir Med. 2015;3(1):24-32.

26. McIntyre LA, Stewart DJ, Mei SHJ, Courtman D, Watpool I, Granton J, Marshall J, Dos Santos C, Walley KR, Winston BW, Schlosser K, Fergusson DA, Canadian Critical Care Trials Group; Canadian Critical Care Translational Biology Group. Cellular immunotherapy for septic shock. A phase I clinical trial. Am J Respir Crit Care Med. 2018;197(3):337-47. https://doi.org/10.1164/ rccm.201705-10060C.

27. Francois M, Copland IB, Yuan S, Romieu-Mourez R, Waller EK, Galipeau J. Cryopreserved mesenchymal stromal cells display impaired immunosuppressive properties as a result of heat-shock response and impaired interferon-gamma licensing. Cytotherapy. 2012;14(2):147-52.

28. Moll G, Alm JJ, Davies LC, et al. Do cryopreserved mesenchymal stromal cells display impaired immunomodulatory and therapeutic properties? Stem Cells. 2014;32(9):2430-42.

29. Devaney J, Horie S, Masterson C, et al. Human mesenchymal stromal cells decrease the severity of acute lung injury induced by $\mathrm{E}$. coli in the rat. Thorax. 2015;70(7):625-35.

30. Gramlich OW, Burand AJ, Brown AJ, Deutsch RJ, Kuehn MH, Ankrum JA Cryopreserved mesenchymal stromal cells maintain potency in a retinal ischemia/reperfusion injury model: toward an off-the-shelf therapy. Sci Rep. 2016;6:26463.

31. Cruz FF, Borg ZD, Goodwin M, et al. Freshly thawed and continuously cultured human bone marrow-derived mesenchymal stromal cells comparably ameliorate allergic airways inflammation in immunocompetent mice. Stem Cells Transl Med. 2015;4(6):615-24.

32. Luetzkendorf J, Nerger $\mathrm{K}$, Hering J, et al. Cryopreservation does not alter main characteristics of good manufacturing process-grade human multipotent mesenchymal stromal cells including immunomodulating 
potential and lack of malignant transformation. Cytotherapy. 2015;17(2):18698.

33. Higgins JPT, Green S. Cochrane Handbook for Systematic Reviews of Interventions Version 5.1.0 [updated March 2011]. The Cochrane Collaboration; 2011 [cited 2018 Sep 25]. Available from: www.handbook. cochrane.org.

34. Moher D, Liberati A, Tetzlaff J, Altman D, group P. Preferred reporting items for systematic reviews and meta-analyses: the PRISMA statement. PLOS Med. 2008;6(7). https://doi.org/10.1371/journal.pmed.1000097.

35. Mei SH, Haitsma JJ, Dos Santos CC, Deng Y, Lai PF, Slutsky AS, et al. Mesenchymal stem cells reduce inflammation while enhancing bacterial clearance and improving survival in sepsis. Am J Respir Crit Care Med. 2010; 182:1047-57.

36. dos Santos CC, Murthy S, Hu P, Shan Y, Haitsma JJ, Mei SH, et al. Network analysis of transcriptional responses induced by mesenchymal stem cell treatment of experimental sepsis. Am J Pathol. 2012;181:1681-92.

37. Gonzalez-Rey E, Anderson P, González MA, Rico L, Büscher D, Delgado M. Human adult stem cells derived from adipose tissue protect against experimental colitis and sepsis. Gut. 2009:58:929-39.

38. Libby P. Inflammatory mechanisms: the molecular basis of inflammation and disease. Nutr Rev. 2008;65. https://doi.org/10.1111/j.1753-4887.2007. tb00352.x.

39. Galipeau J. The mesenchymal stromal cells dilemma--does a negative phase III trial of random donor mesenchymal stromal cells in steroid-resistant graft-versus-host disease represent a death knell or a bump in the road? Cytotherapy. 2013;15(1):2-8.

40. Galipeau J, et al. International Society for Cellular Therapy perspective on immune functional assays for mesenchymal stromal cells as potency release criterion for advanced phase clinical trials. Cytotherapy. 2016;2(18):151-9. https://doi.org/10.1016/j.jcyt.2015.11.008.

41. Hooijmans CR, et al. SYRCLE's risk of bias tool for animal studies. BMC Med Res Methodol. 2014;14:1. https://doi.org/10.1186/1471-2288-14-43.

42. Elshafay A, Omran ES, Abdelkhalek M, et al. Reporting quality in systematic reviews of in vitro studies: a systematic review. Curr Med Res Opin. 2019; 35(9):1631-41. https://doi.org/10.1080/03007995.2019.1607270.

43. Higgins Julian PT, Altman Douglas G, Gøtzsche Peter C, Peter J, David M, Oxman Andrew D, et al. The Cochrane Collaboration's tool for assessing risk of bias in randomised trials. BMJ. 2011;343:d5928.

44. Sarkis-Onofre R, et al. The role of resin cement on bond strength of glassfiber posts luted into root canals: a systematic review and meta-analysis of in vitro studies. Oper Dent. 2014;39(1). https://doi.org/10.2341/13-070-lit.

45. Golbach LA, et al. Calcium homeostasis and low-frequency magnetic and electric field exposure: a systematic review and meta-analysis of in vitro studies. Environ Int. 2016;92-93:695-706. https://doi.org/10.1016/j.envint. 2016.01.014

46. Friedrich JO, Adhikari NK, Beyene J. The ratio of means method as an alternative to mean differences for analyzing continuous outcome variables in meta-analysis: a simulation study. BMC Med Res Methodol. 2008;8:32. https://doi.org/10.1186/1471-2288-8-32.

\section{Publisher's Note}

Springer Nature remains neutral with regard to jurisdictional claims in published maps and institutional affiliations.

Ready to submit your research? Choose BMC and benefit from:

- fast, convenient online submission

- thorough peer review by experienced researchers in your field

- rapid publication on acceptance

- support for research data, including large and complex data types

- gold Open Access which fosters wider collaboration and increased citations

- maximum visibility for your research: over $100 \mathrm{M}$ website views per year

At BMC, research is always in progress.

Learn more biomedcentral.com/submissions 